Crop Breeding and Applied Biotechnology S2: 7-14, 2012

Brazilian Society of Plant Breeding. Printed in Brazil

\title{
Contribution and perspectives of quantitative genetics to plant breeding in Brazil
}

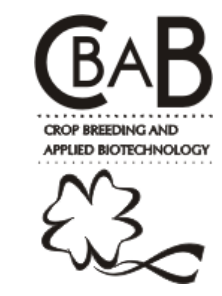

Roland Vencovsky ${ }^{1}$, Magno Antonio Patto Ramalho ${ }^{2 *}$ and Fernando Henrique Ribeiro Barrozo Toledo ${ }^{1}$

Received 15 September 2012

Accepted 03 October 2012

\begin{abstract}
The purpose of this article is to show how quantitative genetics has contributed to the huge genetic progress obtained in plant breeding in Brazil in the last forty years. The information obtained through quantitative genetics has given Brazilian breeders the possibility of responding to innumerable questions in their work in a much more informative way, such as the use or not of hybrid cultivars, which segregating population to use, which breeding method to employ, alternatives for improving the efficiency of selection programs, and how to handle the data of progeny and/or cultivars evaluations to identify the most stable ones and thus improve recommendations.
\end{abstract}

Key words: Genetic parameters, genotype by environment interaction, hybrid cultivars, stability and adaptability.

\section{INTRODUCTION}

Plant breeding has been conceptualized in different manners throughout its history. In the concept proposed by Kempthorne (1957) "plant breeding is applied quantitative genetics." Considering that he was a biometrician, it is easy to understand the importance directed to quantitative genetics in the context of plant breeding. In contrast, for Allard (1999), an evolutionist, plant (or animal) breeding is: "the controlled evolution of plant and animals by humans with the goal of producing populations that have superior agricultural and economic characteristics." A broader concept was presented by Bernardo (2010): "plant breeding is the science, art, and business of improving plants for human benefit." In this last description, it is explicit that the breeding that involves art (the ability of individual in creating a desired model of plant) was mainly used during the domestication of cultivated species.

Breeding also involves science, which began as of the rediscovery of Mendel's work in 1900. The accumulation of knowledge of the 20th Century was responsible for reaching high levels of productivity and meeting the great demand for grains, fruit and fibers of the planet's population. Bernardo (2010) also emphasizes that the breeder must be a manager and, thus, should make the most effective/efficient decisions. In terms of plant breeding the decisions to be made require good knowledge of quantitative genetics because most of the interest traits are quantitative.
Therefore, this article was written up with the purpose of commenting some of the innumerable aspects of quantitative genetics in Brazil that contributed to decision-making of breeders, creating good managers and, above all, showing that in recent decades, many decisions of Brazilian breeders have been based on knowledge from quantitative genetics.

\section{HISTORY OF QUANTITATIVE GENETICS IN BRAZIL}

Plant breeding in Brazil began with the introduction of plants by immigrants at the beginning of the $20^{\text {th }}$ Century and made for considerable advances; however, still as an art (Hunnicutt 1924). The creation of the Instituto Agronômico de Campinas (Agronomy Institute of Campinas), and of some agronomy schools in the same period, was decisive for its development in the country.

One of the important facts for the study of genetics in Brazil was the arrival of professor Friedrich Gustav Brieger from Germany in 1936. He was the precursor of the Genetics Institute of the Escola Superior de Agricultura "Luiz de Queiroz" (ESALQ) ("Luiz de Queiroz" College of Agriculture), where he created, in 1964, the first academic program in genetics and plant breeding in Brazil. As of that time, professors with qualification in quantitative genetics came to be part of that department who began their research advising many undergraduate and graduate students in plant breeding as a science.

\footnotetext{
${ }^{1}$ Universidade de São Paulo, Escola Superior de Agricultura "Luiz de Queiroz" (USP/ESALQ), Departamento de Genética, C.P. 9, 13.418-900, Piracicaba, SP, Brazil

${ }^{2}$ Universidade Federal de Lavras (UFLA), Departamento de Biologia, Campus Universitário, 37.200-000, Lavras, MG, Brazil. * E-mail: magnoapr@dbi.ufla.br
} 
The ESALQ academic program qualified professors from other brazilian universities, such as the following: Universidade Federal de Viçosa, Universidade Federal de Lavras, Universidade Federal de Goiás and others, and also researchers from public and private companies that had breeding programs. This allowed graduation of a core group with knowledge of quantitative genetics for other regions, with new academic programs in genetics and breeding being created, as a rule, by former $E S A L Q$ students. Making an analogy with the pedigree method, it is like having an $F_{2}$ population at $E S A L Q$, in which an expressive number of specialists in quantitative genetics were qualified.

Around in the last four decades, with greater availability of qualified professionals, associated to the sciences development and computational advances, the quantity of useful information for plant breeding has grown enormously. Some of these contributions will be briefly commented below. Adescription of various methods of quantitative genetics of interest to breeders, accompanied by illustrative examples, is given by Vencovsky and Barriga (1992), Cruz et al. (2001), Resende (2002), Hallauer et al. (2010) and Ramalho et al. (2012).

\section{CONTRIBUTIONS OF QUANTITATIVE GENETICS TO DECISION-MAKING BY PLANT BREEDERS}

It has already been mentioned that breeders are managers and, in this work, they must often make decisions. For many of these decisions, scientific knowledge is fundamental. As an example of decisions/questioning, we have:
a) Whether or not to use hybrid cultivars?
b) Which segregating population to use?
c) Which breeding method should be used?
d) How is it possible to increase the efficiency of breeding programs?

e) Can the cultivar obtained be recommended for all regions?

These and many other questions may be answered based on the information provided by quantitative genetics, as will be shown below:

\section{a) Whether or not to use hybrid cultivars?}

The question of whether or not to use hybrid cultivars is strictly related to the magnitude of heterosis of important traits. Heterosis may be defined as superiority of the hybrid in relation to the mean value of the parents and it is a phenomenon known for more than 100 years (Shull 1908). Without a doubt, heterosis led to the development of the entire seed industry, which is responsible for various billions of dollars annually.
Heterosis $(h)$ is dependent on the existence of dominance $(\delta)$, epistasis interactions and genetic divergence between parents $(y)$. As given by Falconer and Mackay (1996), $h=\delta y^{2}$. Thus is true for the cross between two inbred lines as well as for intervarietal crosses.

Considering random mating populations or arbitrary $F_{2}$ generations derived from inbred lines, the mean value of a trait for such materials can be expressed as $\bar{Y}=m+a+d$, ignoring experimental error and epistasis. In this expression $a$ and $d$ are the contribution of homozygotes and heterozygotes, respectively. After one generations of self-fertilization the mean becomes $\bar{Y}_{1}=m+a+(1 / 2) d$ and the contribution of $d$ is reduced by $1 / 2$ for every additional generation of selfing without selection. At the limit, as the inbreeding coefficient approaches $F=1$, the mean tends to $\bar{Y}_{\infty}=m+a$. This quantity is estimable and corresponds to the mean of all possible pure lines obtained from the population. It can, therefore, be used as criterion for the choice of the most adequate population as source of inbred lines.

In Brazil, estimates of $m+a$ and $d$ have been obtained for some crop species. Table 1 shows estimates of the dominance component of population mean $(d)$. Since this component is a consequence of the level of heterozigosity and of dominance effects it is closely related with heterosis. It may be observed (Table 1) that for maize the contribution of $d$ is quite expressive. For common bean, clearly the opposite occurs. Thus, it is easy to understand why hybrid cultivars are used for maize and not for common bean.

\section{b) Which segregating population to use?}

This theme has been one of the most frequent. For that reason, it was one of the main challenges to overcome by geneticists/breeders. This lead to developping methods that aid in decision-making in regard to which population(s) deserve(s) greater attention from breeders. For that reason, various methods have been proposed. Undoubtedly, the major among them are diallel design both in breeding of self and cross-pollination species. The procedures for analysis of diallels were developed in the 1950s and 1960s (Griffing 1956, Gardner and Eberhart 1966). In Brazil, they were greatly used and improved (Miranda Filho and Geraldi 1984). Diallels were used not only for understanding heterosis, but also for the estimation of variance components and of general and specific combining abilities (Hallauer et al. 2010).

Other methods were also used, such as the estimate of $m+a$ to predict beforehand the mean performance of $n$ different lines in a segregating population (Vianna et al. 1982). This procedure was associated with the magnitude of $d$ as a measure to compare two or more populations in relation to 
Table 1. Estimates of the dominance components $(d)$ of populations means, in percentage of the mean value, for several species (grain yield)

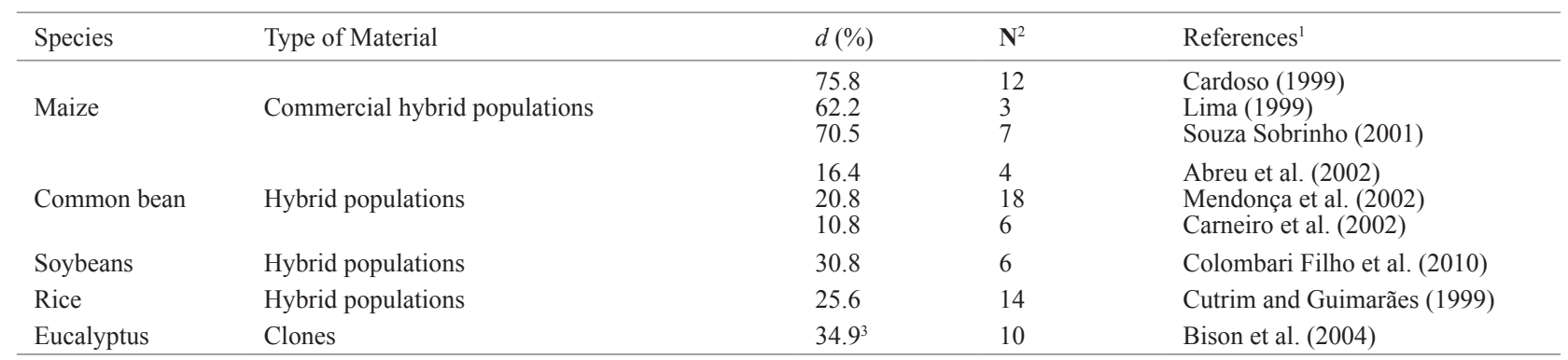

${ }^{1}$ Adapted from Ramalho et al. (2012)

${ }^{2}$ Number of populations evaluated

${ }^{3}$ Circumference at chest height.

the number of segregating loci and thus foresee the genetic variability of these population. Abreu et al. (2002) compared four segregating populations of common bean and estimated $m+a$ and $d$ in parents, $F_{1}$ and $F_{2}$ generations, and in $F_{5: 7}$ progenies, simultaneously evaluated. The results are shown in Table 2. The high estimate of the association between the estimates of $m+a$ and the mean values of the $F_{5 \cdot 7}$ progenies shows that $m+a$ reflected the mean values of the progenies in $F_{\infty}$ since in $F_{5: 7}$ most of the loci are already in homozygosis. Large agreement was also observed among the estimate of $d$ and the genetic variance between $F_{5: 7}$ progenies, showing that the estimate of $d$ allows making inferences in respect to genetic variation in future generations.

\section{c) Which breeding method should be used?}

Another frequent question is which breeding method to use. In cross-pollination species, one may make use of intra or interpopulation recurrent selection (reciprocal recurrent selection). The first aims is to increase the mean value per se of the segregating population, while the second aims to improve heterosis of the cross among two parental populations. The decision of which method to use is not easy and of course depends on the existence of heterosis in the cross between those populations. But what is the magnitude of heterosis?

In face of various selection methods available, it is often difficult to decide on which is better. Comparing them in practice is not a simple task, due to the time and resources necessary for obtaining reliable results. Quantitative genetics may be useful since the comparisons may be made through simulation or numerical evaluation. In this subject, comparison of the intrapopulation recurrent selection procedures were made by Ramalho (1977), based on half sib progenies, and also full sib progenies. The author observed that there was not a single method superior in all situations. The main conclusion was that half sib selection tends to be superior when the evaluation trials have better experimental precision. When precision is worse, as indicated by the coefficient of variation, the full sib method tends to be better.

Vencovsky (1987) and Resende (2002) comment on how to make such decisions in the case of reciprocal recurrent selection. For one locus, interpopulation genetic variance $\left(V_{G}\right)$ is a function of: $V_{G}=1 / 2\left(V_{A 12}+V_{A 21}\right)+V_{D 12}$, where $V_{A 12}$ and $V_{A 21}$ are reciprocal additive genetic variances; the first one deals with additive variance of population 1 when crossed with 2; and $V_{A 21}$ is the additive variance of population 2 when crossed with population 1 . The ratio $\left(V_{A 12}+V_{A 21}\right) /\left(V_{A 11}\right.$ $\left.+V_{A 22}\right)$ when greater than 1 indicates that reciprocal recurrent selection is the best option; otherwise intrapopulation selection is recommended. It is shown that reciprocal recurrent selection will be advantageous when the frequency of the favorable allele $(p)$ (considering $p_{1}$ and $p_{2}$ for populations 1 and 2 , respectively) are low, and when the sum of these frequencies is less than $1\left(p_{1}+p_{2}<1\right)$. Nevertheless, it should be emphasized that the degree of dominance may also have effect on this decision (Vencovsky 1987).

Table 2. Mean values of grain yield of parents, $F_{1}$ and $F_{2}$ generations and $F_{5: 7}$ progenies. Estimates of $m+a, d$, genetic variances among $F_{5: 7}$ progenies and corresponding $h^{2}$ values. Data from four segregating populations ${ }^{1}$

\begin{tabular}{|c|c|c|c|c|c|c|c|c|}
\hline \multirow{2}{*}{ Segregating populations } & \multicolumn{3}{|c|}{ Mean $\left(\mathrm{g}\right.$ plant $\left.{ }^{-1}\right)$} & \multirow{2}{*}{$m+a$} & \multirow{2}{*}{$d$} & \multirow{2}{*}{$F_{G_{F_{5: 7}}}$} & \multirow{2}{*}{$h^{2}$} & \multirow{2}{*}{$\begin{array}{l}\text { Mean value of the prog- } \\
\text { enies } F_{5: 7}\left(\mathrm{~g} \text { plot }{ }^{-1}\right)\end{array}$} \\
\hline & Parents & $F_{1}$ & $F_{2}$ & & & & & \\
\hline 1 & 12.0 & 12.1 & 11.4 & 11.8 & 0.1 & 124.5 & 18.5 & 285.8 \\
\hline 2 & 13.9 & 14.1 & 12.5 & 13.4 & 0.3 & 332.5 & 26.0 & 286.4 \\
\hline 4 & 7.9 & 12.8 & 9.8 & 7.7 & 5.0 & 882.9 & 52.4 & 231.8 \\
\hline
\end{tabular}

${ }^{1}$ Adapted from Abreu et al. (2002). 
In self-pollination species, expertise in quantitative genetics also aids in many researchers decisions. It is known that the genetic variance components related to the generation, varies according to the inbreeding coefficient (Souza Júnior 1989, Ramalho et al. 2012). In Table 3 the coefficients of $V_{A}$ and $V_{D}$ in successive generations of self-pollination are shown. It may be observed that with inbreeding, additive variance $\left(V_{A}\right)$ increases, while dominance variance $\left(V_{D}\right)$ decreases. At the limit $\left(F_{\infty}\right)$, it is twice the additive variance present in $F_{2}$. In this generation, there are no loci in heterozygosis, thus there is no more dominance variance. With this knowledge, the breeder may make many decisions. For instance, using bulk within progenies, should this begin in $F_{2}$ or $F_{3}$ ? Using the $F_{3}$ generation, $50 \%$ more of the $V_{A}$ found in $F_{2}$ will be exploited, which is a considerable advantage. Another case is when one should open the bulk, in $F_{4}$ or $F_{5}$ ? It may be observed that the increase of additive variance from $F_{5}$ to $F_{4}$ is very small, which does not justify the postponement of one more generation, to begin the selective process. These and many other decisions are routinely made based on the data shown in Table 3.

Table 3. Fractions of additive and dominance variance in successive generations of self-pollination species with allelic frequency equal to 0.5

\begin{tabular}{cccc}
\hline Generation & $\begin{array}{c}\text { Inbreeding } \\
\text { Coefficient }\end{array}$ & $V_{A}$ & $V_{D}$ \\
\hline$F_{2}$ & 0 & 1 & 1 \\
$F_{3}$ & $1 / 2$ & $3 / 2$ & $3 / 4$ \\
$F_{4}$ & $3 / 4$ & $7 / 4$ & $7 / 16$ \\
$F_{5}$ & $7 / 8$ & $15 / 8$ & $15 / 64$ \\
$F_{6}$ & $15 / 16$ & $31 / 16$ & $31 / 256$ \\
$\vdots$ & $\vdots$ & $\vdots$ & $\vdots$ \\
$F_{\infty}$ & 1 & 2 & 0 \\
\hline
\end{tabular}

\section{d) How is it possible to increase the efficiency of breeding programs?}

Breeders should always seek to have the maximum genetic progress. How can this greater efficiency be obtained? Here also quantitative genetics has provided important contributions both in self and cross-pollination species. Actually, there are many publications of Brazilian geneticists providing these information in an applied and accessible way (Souza Júnior 1989, Vencovsky and Barriga 1992, Cruz et al. 2001, Resende 2002, Ramalho et al. 2012).

The general expression of genetic gain $(G S)$ is:

$$
G S=i c \frac{V_{A}}{\sqrt{V_{F}}},
$$

where:

$i$ is the standardized selection intensity; a fixed value that depends on the proportion of individuals and/or progenies selected (which may be used when the data are normally distributed); $c$ is the proportion of additive genetic variance used in the selection generation; in self-pollination species, it is related to the covariance between the generation in which selection was carried out and the $F_{\infty}$ generation. In cross-pollination species, the coefficient $c$ depends on the type of progeny evaluated and the unit of recombination;

$V_{A}$ is the additive genetic variance and depends on the genetic variance of the population ignoring epistasis. For that reason, one should seek to identify the population that is segregating for a large number of loci; and

$V_{F}$ is the phenotypic variance of the selection unit.

In order to have expressive values of $G S$ without compromising the future success of selection in the population, the greatest feasible number of individuals and/or progenies should be evaluated. This observation is particularly useful for perennial plants in which the selective cycle takes a long time and the greatest possible success must be sought for each cycle. Through the gain estimator, it becomes clear that success from selection may be increased by reduction of the phenotypic variance. In practice, when progenies are evaluated in experiments with $k$ plants per plot, $r$ replications, in $a$ environments, phenotypic variance of these progenies, on a mean basis, contains:

$$
V_{P}=\frac{V_{w}}{k r a}+\frac{V_{e}}{a r}+\frac{V_{p a}}{a}+V_{p} .
$$

In this expression, $V_{p}$ is the genetic variance among progenies, $V_{p a}$ is the variance of the progeny by environment interaction and $V_{w}$ is the phenotypic variance between plants within plots. In most of the cases, $V_{w}$ contains the genetic variance within progenies $\left(V_{g w}\right)$ and the environmental variance among plants within plots $\left(V_{e w}\right)$. The quantity $V_{e}$ is the residual variance between plots that received the same progeny apart of the variations related to experimental design.

Therefore, to reduce $V_{P}$, one of the alternatives is to increase the quantities $a, r$ or $k$. Nevertheless, most of the phenotypic variance is a consequence of experimental precision. Thus, as mentioned before, precise trials in progenies/lines/hybrids evaluation should be an "obsession". Throughout time, diverse studies in the subject of biometrics/quantitative genetics have been performed with a view toward obtaining more precise data and they are being widely currently used (Resende and Duarte 2007).

In maize, estimates of genetic parameters that aid researchers have been accumulated. Vencosvsky et al. (1988) made a survey of some of the estimates obtained in the intrapopulation recurrent selection programs. These authors gathered data from 58 experiments for evaluation and selection of half sib progenies for grain yield (Table 4). It was observed that the estimates of additive genetic variance (mean value) were 
relatively high; heritability for selection of individual plants was low (11\%); even so, progress from progeny selection was on average $11.7 g$ per cycle $([G S=11.7 / 120] \times 100=10 \%)$. This success is due to reasonable experimental precision, as could be evaluated through the experimental coefficient of variation. It was pointed out that obtaining good experimental precision throughout a breeding program is a sine qua non condition for achieving a desired progress.

Table 4. Average estimates of maize ear yield parameters $\left(\mathrm{g} \mathrm{plant}^{-1}\right)$ from 58 experiments for evaluation of half sib progenies conducted in Brazil ${ }^{1}$

\begin{tabular}{ll}
\hline Parameter & Mean estimate \\
\hline$V_{A}\left(g^{2}\right)$ & 309 \\
$h^{2}(\%)$ (individual plant basis) & 11.0 \\
$\mathrm{GS}(\mathrm{g})$ per cycle & 11.7 \\
$C V_{e}(\%)$ & 16.3 \\
Mean $(g)$ per plant & 120 \\
\hline
\end{tabular}

${ }^{1}$ Adapted from Vencovsky et al. (1988).

Many studies have been carried out in recent years aimed at evaluating genetic divergence of parents, either using morphological or molecular markers (Machado et al. 2002, Mendonça et al. 2002). In general, it was shown that the estimate of genetic divergence alone is not sufficient for the choice of parents. Evidence has been accumulated, especially in self-pollination species, indicating the need for crosses among adapted and agronomically superior parents - in "breeding language", crossing good x good parents (Rasmusson and Phillips 1997). With adapted parents, the choice of the most divergent ones is the best strategy for success in selection.

Several methods are available for the choice of the best segregating populations adequate for obtaining superior lines. It is the decision of breeders to concentrate efforts only on the most promising ones. Thus, plant breeding becomes more and more based on scientific knowledge.

\section{e) Can the cultivar obtained be recommended for all growing regions?}

Various studies have been carried out to develop new biometric tools to identify lines/hybrids with greater adaptability and stability (Duarte and Vencovsky 1999). For detecting agricultural zones or regions, these studies have contributed to make $V C U$ (Valor de Cultivo e Uso) [Value for Cultivation and Use] experiments more efficient and, above all, to identify locations that most contribute to genotype by environment interaction (Bertoldo et al. 2009, Castro et al. 2010, Pereira et al. 2010).

The application of knowledge from the genotype by environment interaction $(G E)$ is one of the greatest challenges of breeders. Especially in Brazil, due to the huge range of edaphoclimatic and crop management conditions. Quantitative genetics in Brazil has generated a great deal of information that has allowed mitigating the effects of $G E$ interaction and providing information used for the benefit of breeding programs (Bertoldo et al. 2009, Castro et al. 2010, Pereira et al. 2010).

One of the examples of the contribution of quantitative genetics in the study of the $G E$ interaction was published by Bressiani et al. (2002). The study was carried out with sugarcane crop and involved two locations in São Paulo state, Brazil. Thirty-three families (clones) were evaluated in randomized complete blocks; various traits were considered, however only results on sugarcane yield in tons per hectare will be shown. The estimates of the genetic and phenotypic parameters obtained are shown in Table 5. It was observed that most of the families by locations interaction was of a complex nature, and a low estimate of the genetic correlation between families between locations was found. Consequently, only a single superior family would be selected for both locations. Expected genetic gain reinforces these results (Table 6). It is observed that if selection is practiced in one of the locations (Piracicaba), the response in the other location (Jaú) is negative; selection in one location would imply a decrease of the mean in the other. In contrast, selection based on the average of the two locations led to gain in both, although always inferior to direct selection at the location. This is a situation in which interaction may be capitalized in favor of the breeder; in other words, practicing selection within each location and recommending the clones selected only for that region.

There are various other methods for survey the phenomenon of genotypes by environments interaction in addition to that described above. The most widely used, are based on regression procedures, with focus on the question of stability. Rosse and Vencovsky (2000) used segmented non-linear regression, which allows classifying common bean lines according to their pattern yield response in face of environmental variations between locations. The method used allowed identifying the superior lines for these two agronomic properties.

Table 5. Estimates of genetic and phenotypic parameters of sugarcane yield $\left(\mathrm{t} \mathrm{ha}^{-1}\right)$ obtained in joint analysis of two locations ${ }^{1}$

\begin{tabular}{lc}
\hline Components & Estimates \\
\hline Genetic variance among families & 48.52 \\
Variance of families x locations interaction & 28.05 \\
Simple interaction (\%) & 0.30 \\
Complex interaction (\%) & 99.70 \\
Genetic correlation of family mean & 0.20 \\
values between locations & 12.68 \\
Variance of error among plots & \\
\hline
\end{tabular}

${ }^{1}$ Adapted from Bressiani et al. (2002). 
R Vencovsky et al.

Table 6. Expected genetic gain (\%) of sugarcane yield $\left(\mathrm{t} \mathrm{ha}^{-1}\right)$ from family selection under different alternatives in two locations ${ }^{1}$

\begin{tabular}{lcc}
\hline \multirow{2}{*}{ Selection location } & \multicolumn{2}{c}{ Location of response to selection } \\
\cline { 2 - 3 } & Piracicaba & Jaú \\
\hline Piracicaba & 15.90 & -1.10 \\
Jaú & 0.80 & 8.70 \\
Mean of the two locations & 9.17 & 6.30 \\
\hline
\end{tabular}

${ }^{1}$ Adapted from Bressiani et al. (2002).

\section{THE CONTRIBUTION OF PLANT BREEDING TO CROP SPECIES IN BRAZIL}

One of the activities that is important and concerns all breeders is estimating the genetic progress obtained by their program. The most obvious manner of estimating progress is evaluating, in specific experiments, the cultivars that were obtained throughout the program, since its beginning. The drawback of this type of trial is the problem of not having seeds from the older cultivars/lines/hybrids. An alternative manner for estimating the progress achieved that does not require such specific trails was proposed by Vencovsky et al. (1988). This is based on the analysis of regional or national trials, gathering the data from various years. This method was later improved from the biometric point of view. Currently, estimates of the annual genetic progress in various species are available such as rice (Soares et al. 1999, Atroch and Nunes 2000), common bean (Fonseca Júnior 1997, Matos et al. 2007, Chiorato 2010), maize (Vencovsky 1988), soybeans (Lange and Federizzi 2009), oats (Barbosa Neto et al. 2000) and wheat (Cargnin et al. 2009), which attest to the success of the work of Brazilian breeders.

\section{FINAL CONSIDERATIONS}

It should be mentioned that with the development of computational resources, various statistical programs, including ones developed by Brazilian researchers, have permitted breeders to perform their analyses, without cost, in an easier and more accessible way (Resende 2007). With these computational resources, the use of mixed models came to be routine in breeding programs, especially for perennial plants (Resende 2002). More recently, quantitative geneticists have been envisioning the possibility of expanding the success of selection through genome wide selection (Resende et al. 2008). Quantitative genetics is expected to provide the greatest contributions in this subject, not only providing the tools for data analyses, but evaluating their efficiency in selection programs.

In addition to computational resources, with the advent of molecular marker and genomic techniques, in the last two decades of the 20th Century, quantitative genetics allowed achieving a great effort in application of this important tool. The expected gain from marker assisted selection was the theme of various articles (Muro-Abad et al. 2005). The use of QTLs (quantitative trait loci) was also exhaustively studied
(Mangolin et al. 2004, Sabatin et al. 2008, Santos et al. 2010).

Another aspect of quantitative genetics that has not been sufficiently mentioned is related to publications. There are ever growing requirements for professors/researchers to share their works in qualified and highly respected journals. Without having good published works, breeders have difficulties in getting resources from research sponsor sources in comparison with their peers Consequently they may have difficulties in maintaining their positions as professors in academic graduate programs, as well as, smaller activities in graduate students advisory. Publishing results of breeding programs including quantitative genetics is therefore a good strategy for breeders.

As proof of this, a survey was made of the published studies (Table 7), in two journals related to plant breeding, namely, Pesquisa Agropecuária Brasileira $(P A B)$ and Crop Breeding and Applied Biotecnology $(C B A B)$. $P A B$ is a diversified periodical that publishes articles on subjects of crop and livestock raising and, for that reason, only articles related to breeding were considered. The number of publications related to plant breeding in $P A B$ in the last 12 years has been expressive, and most of them made use of knowledge of quantitative genetics with an emphasis on estimates of genetic parameters for obtaining information on inheritance of traits and of genotype by environment interaction. $C B A B$ is a periodical restricted to plant breeding. In this journal, in the same period, more than $50 \%$ of the articles were related to the quantitative genetics and the distribution of themes was similar to $P A B$ 's distribution. The trend is that publications on themes related to quantitative genetics in Brazil will increase in the coming years.

\section{ACKNOWLEDGEMENTS}

The authors are grateful to the student Indalécio Cunha Vieira Junior and the graduate student Scheila Roberta Guilherme for assistance in the preparation of the manuscript.

Table 7. Number of articles related to quantitative genetics published in the journals Pesquisa Agropecuária Brasileira $(P A B)$ and Crop Breeding and Aplied Biotechonology $(C B A B)$ in the period from 2001 to 2011

\begin{tabular}{lcc}
\hline \multirow{2}{*}{ Themes } & \multicolumn{2}{c}{ Journals } \\
\cline { 2 - 3 } & $\boldsymbol{P A \boldsymbol { B }}$ & $\boldsymbol{C B} \boldsymbol{A B}$ \\
\hline Genotype by environment interaction & 53 & 77 \\
Estimate of genetic parameters & 76 & 134 \\
Choice of parents/diallels $_{\text {Genetic divergence }}$ & 17 & 41 \\
Correlation between traits $_{\text {OTL mapping }}$ & 53 & 92 \\
Other subjects of breeding $^{2}$ & 216 & 21 \\
\hline Total $^{2}$ & 8 & 17 \\
\hline
\end{tabular}

${ }^{1}$ In estimates of parameters are included estimates of gain expected from selection, inheritance and the genotype by environment interaction.

${ }^{2}$ Other studies in breeding which, however, are not related to quantitative genetics. 


\section{Contribuição e perspectivas da genética quantitativa no melhoramento genético de plantas no Brasil}

Resumo - O objetivo desse artigo é evidenciar que a genética quantitativa contribuiu para o enorme progresso genético obtido nas plantas cultivadas no Brasil, nos últimos quarenta anos. As informações obtidas por meio da genética quantitativa possibilitaram que os melhoristas brasileiros pudessem responder, com muito mais ciência, inúmeras questões do seu trabalho tais como: utilizar cultivares hibrida ou não; qual população segregante utilizar; qual método de melhoramento empregar; alternativas para melhorar a eficiências dos programas de seleção e como manusear os dados das avaliações de progênies elou cultivares para se identificar as mais estáveis e assim aprimorar a recomendação.

Palavras-chave: Parâmetros genéticos, interação genótipos por ambientes, cultivares híbridas, estabilidade e adaptabilidade.

\section{REFERENCES}

Abreu AFB, Ramalho MAP and Santos JB (2002) Prediction of seed-yield potential of common bean populations. Genetics and Molecular Biology 25: 323-327.

Allard RW (1999) Principles of plant breeding. $2^{\text {nd }}$ ed., John Wiley \& Sons, New York, 254p.

Atroch AL and Nunes GHS (2000) Progresso genético em arroz de várzea úmida no Estado do Amapá. Pesquisa Agropecuária Brasileira 35: 767-771.

Barbosa Neto JF, Matiello RR, Carvalho FIF, Oliveira JMS, Pegoraro DG, Schneider F, Sordi ME B and Vacaro E (2000) Progresso genético no melhoramento da aveia-branca no sul do Brasil. Pesquisa Agropecuária Brasileira 35: 1605-1612.

Bernardo R (2010) Breeding for quantitative traits in plants. Stemma, Hardbound, 369p.

Bressiani JA, Vencovsky R and Burnquist W (2002) Interação entre famílias de cana-de-açúcar e locais: efeito na resposta esperada com a seleção. Bragantia 61: 1-10.

Bertoldo JG, Coimbra LM, Nodari RO, Guidolin, AF, Hemp S, Barili LD, Vale NM and Rozetto DS (2009) Stratification of the state of Santa Catarina in macro environments for bean cultivation. Crop Breeding and Applied Biotechnology 9: 335-343.

Cargnin A, Souza MA, Fronza V and Fogaca CM (2009) Genetic and environmental contributions to increased wheat yield in Minas Gerais, Brazil. Pesquisa Agropecuária Brasileira 66: 317-322.

Castro JPA (2010) Evaluation of maize hybrids and environmental stratification by the methods $A M M I$ and $G G E$ biplot. Crop Breeding and Applied Biotechnology 10: 247-253.

Chiorato AF, Carbonell SAM, Vencovsky R, Fonseca Júnior NS and Pinheiro JB (2010) Genetic gain in the breeding program of common beans at IAC from 1989 to 2007. Crop Breeding and Applied Biotechnology 10: 329-336.

Cruz CD, Regazzi AJ and Carneiro PCS (2001) Modelos biométricos aplicados ao melhoramento genético. $2^{\text {nd }}$ ed., UFV, Viçosa, 390p.

Duarte JB and Vencovsky R (1999) Interação genótipos $\times$ ambientes: uma introdução à análise " $\boldsymbol{A M M I}$ ". SBG, Ribeirão Preto, 60p. (Série Monografias, 9).
Falconer DS and Mackay TFC (1996) Introduction to quantitative genetics. $4^{\text {th }}$ ed., Longman, London, $463 \mathrm{p}$.

Fonseca Júnior NS (1997) Progresso genético na cultura do feijão no estado do Paraná para o período de 1977 a 1995. ESALQ/ Departamento de Genética, Piracicaba, 168p. (PhD Thesis).

Gardner CO and Eberhart SA (1966) Analysis and interpretation of the variety cross diallel and related population. Biometrics 22: 439-452.

Griffing G (1956) Concept of general and specific combining ability in relation to diallel crossing systems. Australian Journal of Biology Science 9: 463-493.

Hallauer AR, Carena MJ and Miranda Filho JB (2010) Quantitative genetics in maize breeding. $3^{\text {rd }}$ ed., Springer-Verlag, Berlim, 500p.

Hunnicutt BH (1924) O milho, sua cultura e aproveitamento no Brasil. Leite Ribeiro, Rio de Janeiro, 243p.

Kempthorne O (1957) An introduction to genetic statistics. John Wiley \& Sons, New York, 545p.

Lange CE and Federizzi LC (2009) Estimation of soybean genetic progress in the South of Brazil using multi-environmental yield trials. Pesquisa Agropecuária Brasileira 66: 309-316.

Machado CF, Santos JB, Nunes GHS and Ramalho MAP (2002) Choice of common bean parents based on combining ability estimates. Genetics and Molecular Biology 25: 179-183.

Mangolin CA, Souza CL, Garcia AAF, Garcia AF, Sibov ST and Souza AP (2004) Mapping QTLs for kernel oil content in a tropical maize population. Euphytica 137: 251-259.

Matos JW, Abreu AFB and Ramalho MAP (2007) Trinta e dois anos do programa de melhoramento genético do feijoeiro comum em Minas Gerais. Ciência e Agrotecnologia 31: 1749-1754.

Mendonça HA, Santos JB and Ramalho MAP (2002) Selection of common bean segregation populations using genetic and phenotypic parameters and RAPD markers. Crop Breeding and Applied Biotechnology 2: 219-226.

Miranda Filho JB and Geraldi IO (1984) An adapted model for the analysis of partial diallel crosses. Brazilian Journal of Genetics 7: 677-688. 
R Vencovsky et al.

Muro-Abad JI Rocha RB, Cruz CD, Pires IE and Araújo EF (2005) Crosses recommendation method for obtaining Eucalyptus spp. hybrids assisted by molecular markers. Crop Breeding and Applied Biotechnology 5: 71-79.

Pereira HS, Melo LC, Faria LC, Díaz JLC, Del Peloso MJ and Wendland A (2010) Environmental stratification in Paraná and Santa Catarina to evaluate common bean genotypes. Crop Breeding and Applied Biotechnology 10: 132-139.

Ramalho MAP (1977) Eficiência relativa de alguns processos de seleção intrapopulacional no milho baseados em famílias não endogâmicas. ESALQ/Departamento de Genética, Piracicaba, 122p. (PhD Thesis).

Ramalho MAP, Abreu AFB, Santos JB and Nunes JAR (2012) Aplicações da genética quantitativa no melhoramento de plantas autógamas. UFLA, Lavras, 522p.

Rasmusson DC and Phillips RL (1997) Plant breeding progress and genetic diversity from de novo variation and elevated epistasis. Crop Science 37: 303-310.

Resende MDV (2002) Genética biométrica e estatística no melhoramento de plantas perenes. Embrapa Informação Tecnológica, Brasília, 975p.

Resende MDV (2007) Selegen-Reml/Blup: sistema estatístico e seleção genética computadorizada via modelos lineares mistos. Embrapa Florestas, Colombo, 360p.

Resende MDV and Duarte JB (2007) Precisão e controle de qualidade em experimentos de avaliação de cultivares. Pesquisa Agropecuária Tropical 37: 182-194.

Resende MDV, Lopes OS, Silva RL and Pires IE (2008) Seleção genômica ampla (GWS) e maximização da eficiência do melhoramento genético. Pesquisa Florestal Brasileira 56: 63-78.

Rosse LN and Vencovsky R (2000) Modelos de regressão não-linear aplicado ao estudo da estabilidade fenotípica de genótipos de feijão no estado do Paraná. Bragantia 59: 99-107.
Sabadin KP (2008) QTL mapping for yield components in a tropical maize population using microsatellite markers. Hereditas 145: 194-203.

Santos FHC, Cavalcanti JJV and Silva FPDA (2010) Detection of quantitative trait loci for physical traits of cashew apple. Crop Breeding and Applied Biotechnology 10: 101-109.

Shull GH (1908) The composition of a field of maize. American Breeding Association Reports 4: 296-301.

Soares AA, Santos PG, Morais OP, Soares PC, Reis MS and Souza MA (1999) Progresso genético obtido pelo melhoramento de arroz de sequeiro em 21 anos de pesquisa em Minas Gerais. Pesquisa Agropecuária Brasileira 34: 415-24.

Souza Júnior CL (1989) Componentes da variância genética e suas implicações no melhoramento vegetal. FEALQ, Piracicaba, 134p.

Vianna RT, Gama EEG, Vencovsky R and Vello NA (1982) Inbreeding depression of several introduced populations of maize. Maydica 28: 151-157.

Vencovsky R (1987) Herança quantitativa. In Paterniani E and Viégas GP (Org.) Melhoramento e produção do milho no Brasil. Fundação Cargil, Campinas, p. 122-199.

Vencovsky R, Miranda Filho JB and Souza Júnior CL (1988) Quantitative genetics and corn breeding in Brazil. In Weir B, Eisen B, Goodman MM and Namkoong N (eds.) Proceeding of the second international conference on quantitative genetics. Sinauer, Sunderland, p. 465-477.

Vencovsky R, Moraes AR and Garcia JC (1988) Progresso genético em vinte anos de melhoramento de milho no Brasil. In Anais do $\mathbf{1 6}^{\mathbf{0}}$ congresso nacional de milho e sorgo. Embrapa CNPMS, Belo Horizonte/Sete Lagoas p. 300-307.

Vencovsky R and Barriga P (1992) Estatística biométrica no fitomelhoramento. Revista Brasileira de Genética, Ribeirão Preto, 496p. 